On Reading the Constitution 



\section{On Reading the Constitution}

Laurence H. Tribe \& Michael C. Dorf

Harvard University Press

Cambridge, Massachusetts, and London, England 


\section{Copyright (C) 1991 by the President and Fellows of Harvard College All rights reserved \\ Printed in the United States of America}

This book has been digitally reprinted. The content remains identical to that of previous printings.

An earlier version of Chapters $I$ and 2 originally appeared in the Tanner Lectures on Human Values, vol. 9, reprinted by permission of the University of Utah Press.

This book is printed on acid-free paper, and its binding materials have been chosen for strength and durability.

\section{Library of Congress Cataloging-in-Publication Data}

Tribe, Laurence $\mathrm{H}$.

On reading the Constitution / Laurence $\mathrm{H}$. Tribe and Michael C. Dorf.

$$
\text { p. cm. }
$$

Includes bibliographical references and index.

ISBN 0-674-63625-2 (alk. paper)

I. United States-Constitutional law-Interpretation and construction.

I. Dorf, Michael C. II. Title.

$\mathrm{KF}_{4550 . T 787}$ I99I

$34^{2} .73^{\prime} \mathrm{O} 2-\mathrm{dc} 2 \mathrm{O}$

[347.3022] 90-47064

CIP 
For Polia Tribe and the memory of George Tribe, and for Annette and Stanley Dorf 
